УДК 811.11

DOI: 10.33184/YVDK-2021-04-30.59

А.С. Самигуллина (проф. БашГУ, г. Уфа), Д.Ю. Дмитриева (ст.npen. БаиГУ, г. Уфа)

\title{
ОПИСАНИЕ ИНТЕЛЛЕКТУАЛЬНЫХ СПОСОБНОСТЕЙ ЧЕЛОВЕКА В ВЕРБАЛЬНОЙ И НЕВЕРБАЛЬНОЙ СЕМИОТИКЕ (НА МАТЕРИАЛЕ АНГЛИЙСКОГО ЯЗЫКА)
}

В статье рассматриваются способь описания интеллектуальных способностей человека в английском языке с позиции вербальной и невербальной семиотики.

Ключевые слова: интеллектуальные способности человека, знак, вербальная семиотика, невербальная семиотика.

The article deals with different ways of expressing the intellectual abilities of a person from the standpoint described in verbal and non-verbal semiotics.

Key words: intellectual abilities of a person, sign, verbal semiotics, non-verbal semiotics.

Человек живет в мире вещей, и всякая вещь служит знаками. Человек непрерывно, на протяжении всей жизни, получает информацию, перерабатывает, кодирует и передает ее, говоря о знаках и используя знаки. Уже в античности создаются учения о знаках. Первое общее определение знака дает Св.Августин в трактате о «Христианском учении», где знак определяется, как вещь, которая помимо формы, напечатлеваемой в чувствах, дает из себя узнать нечто другое. Но еще до Св.Августина о знаках говорят Платон и Аристотель в узко-лингвистическом понимании [Вдовина 2009: 11].

Люди общаются между собой не только с помощью слов, но и посредством телесных движений. Каждый из атрибутов тела, будь то форма, размер, положение или рост, при определенных условиях выражает или передает некоторое значение. Между 
жестовыми и естественными языками наблюдается определенное сходство. Параллельное существование и взаимодействие языка тела и языка слов в коммуникативном акте возможно в силу того, что глубинные процессы, лежащие в основании невербальной и вербальной деятельности человека, по всей видимости, в существенных отношениях аналогичны [Крейдлин 2002: 46]. Для начала рассмотрим один общеизвестный жест, используемый англичанами для описания глупости. Он удобен, когда сказать вслух, что определенный человек - дурачок, нельзя, этот человек услышит, а вот показав своему собеседнику данный знак, пока тот, о котором идет речь, не видит, можно. Такой жест называется "the cuckoo sign". Англичане считаются сдержанными, но все же их речь тоже сопровождается жестами. Например, в произведении О.Хаксли «Остров» местная жительница, рассказывая про себя попавшему на их остров иностранцу, использует жест, говоря о своих интеллектуальных возможностях: "More intelligent on that level," said Mrs.Rao, "even though one may be very stupid upstairs". She patted on the top of her head. "I'm too dumb to be any good at the things that Dr. Robert and Vijaya are good at - genetics and biochemistry and philosophy and all the rest". [A.Huxley 2002: 78]. В данном примере постукивание по голове служит знаком, обозначающим определенный уровень способностей человека, а именно глупость. У англичан, как и многих других народов, кручение указательным пальцем у виска или постукивание по голове означает, что кто-то, о ком идет речь, глупый и сумасшедший.

Говоря об интеллектуальных способностях и знаках, можно сказать, что внешность человека служит для нас понятием, а образ и оценочное суждение - акустическим образом. Знакомясь с новым человеком, мы, как правило, по внешности, по манере говорить можем определить какого рода человек перед нами, опираясь на опыт. В таких случаях форма головы, рост и т.д. служат знаками. В английском языке есть немало примеров, свидетельствующих об этом. На следующих примерах покажем, что может служить знаком и на что указывать. Одним из главных признаков умного человека - это большая голова и широкий лоб. Голова ассоциируется с вместилищем, куда должна складываться информация - чем больше вместилище, тем больше информации может быть заложено, следовательно, тем умнее человек: You 
need a big head for studying, it's a bit difficult [BNC]. The handsome young Annamese in his early twenties who offered his hand promptly to Joseph and his mother had the piercing gaze and broad forehead of a scholar [BNC]. А маленькая голова с узким лбом указывает на невысокий уровень интеллекта: Damn it all, woman, I would have thought that talk you had in the car park with your two 'friends' would have knocked some sense into your stubborn little head, but obviously it didn't [BNC]! Вышеперечисленные примеры говорят о логичности мышлении, но иногда, один из собеседников может сделать заключение, противоречивое первому впечатлению: A big head and little wit [АППИРС]. Данная оценка интеллекту дается уже по истечении времени.

Глаза и взгляд человека также помогают нам создать образ умного или глупого человека. Умные глаза как будто вслед за мыслью то двигаются, ищут ответ на вопрос, то останавливаются на предмете, чтобы сконцентрироваться: These reflections have dispelled the agitation with which I began my letter, and I feel my heart glow with an enthusiasm which elevates me to heaven, for nothing contributes so much to tranquillize the mind as a steady purpose-a point on which the soul may fix its intellectual eye.[M. Shelley] 'We're under the Clyde now,' he cast an intellectual eye at the roof of the carriage [BNC]. He looked sharply at Corbett, his tired, clever eyes searching the English clerk's face.[BNC] Глаза неумного человека при описании всегда соотносятся с открытым ртом: After an evening of work here, she felt she must look like a cod or haddock herself with dull eyes and open mouth. Instead of just mooning about with your mouth open, like the village idiot, why not do something intelligent for a change? [A.Huxley]

Уровень интеллекта определяется по умению доносить свою мысль правильно. Умный человек обладает большим лексиконом, и выразить свою мысль для него не составляет труда. Он думает, прежде что-либо сказать. А вот глупый человек порой за неимением нужных слов в голове, говорит много, причем очень часто отходя от объекта речи. Поэтому во всех английских пословицах болтливый человек предстает глупым - человек, который говорит много, не задумываясь. Ср.: A fool's tongue runs before his wits. - A still tongue makes a wise head [АППИРС ].

Бытует мнение, что красивые люди умнее, чем менее красивые. Это объясняется тем, что успешные мужчины в 
качестве жены выбирают красивых женщин, у них рождаются красивые дети. Дети получают хорошее образование, и генофонд пополняется красивыми и умными людьми: Researchers have found that handsome men and beautiful women tend to be cleverer, with IQs averaging up to nearly 14 points above the norm [The Sunday Times]. Также существует точка зрения, что очень привлекательные женщины - неумные. Многие воспринимают блондинок с пышной грудью как глупых женщин: 1) We instead believe that the stereotype is that blonde women and women with large breasts are unintelligent, both of which, just like the stereotype that beautiful people are intelligent, may statistically be true [The Guardian].

Высокие люди считаются умными: чем выше, тем умнее: Tall people are smarter. Or perhaps people who were both taller and smarter get more mating opportunities, making it an evolved tendency [The Guardian]. But the discrepancy is explained mainly by discrimination, the simple fact that society tends to look on tall people as more powerful and smarter, even when they're not [BBC]. Соответственно люди с низким ростом представляются не столь умными: THEY are prone to paranoia and poor mental health and tend to be jealous lovers. Now it seems the vertically challenged can also suffer from low intelligence, according to scientists [The Sunday Times]. Таким образом, рост служит знаком, по которому дается оценка умственным способностям человека. Также удалось выделить другие характеристики, служащие знаками, а именно половая принадлежность, манера говорить (диалект), расовая принадлежность, профессия, религиозные убеждения.

Итак, при описании интеллектуальных способностей человека часто обращают внимание на такие данные, как внешность, рост, размер головы или лба, пол, раса, манера говорить (диалект), пол, раса, профессия, религиозные убеждения, выступающие в качестве знаков для параметризации оценки умственных способностей человека.

\section{ЛИТЕРАТУРА}

1. Вдовина Г.В. Язык неочевидного. Учения о знаках в схоластике XVII в.. - M.: Институт философии, теологии и истории св. Фомы, 2009. - 648 с. 
2. Крейдлин Г.Е. Невербальная семиотика: Язык тела и естественный язык. - М.: Новое литературное обозрение, 2002. - 592 с.

3. АППИРС - английские пословицы и поговорки и их русские соответствия / В.С.Модестов. - 7-е изд., стереотип. - М.: Рус.яз. - Медиа, 2008. - 467 c.

4. Huxley A. Island. Perennial classic ed.p.cm., 2002.$354 \mathrm{p}$.

5. Shelley M. Frankenstein or the Modern Prometheus. Спб.:КОРОНА принт, КАРО, 2004. - 368 с.

6. ВBC - British Broadcasting Corporation. [Электронный pecypc]. URL: https://www.bbc.com (дата обращения: 13.03.2014).

7. BNC - British National Corpus. [Электронный pecypc]. URL: http://www.natcorp.ox.ac.uk (дата обращения: 01.03.2014).

8. The Guardian. [Электронный pecypc]. URL: https://www.theguardian.com (дата обращения: 13.03.2014).

9. The Sunday Times. [Электронный pecypc]. URL: https://www.thetimes.co.uk (дата обращения: 13.03.2014).

(С)СаигуллинА.С., Дмитриева Д.Ю., 2021 г. 